\title{
Analisis Sifat Fisik, Sifat Organoleptik, dan Kandungan Gizi pada Produk Tempe dari Kacang Non-Kedelai
}

\section{Analysis of Physical Properties, Organoleptic Properties, and Nutritional Values of Tempeh From Non-} Soybean Legumes

Ani Radiati, Sumarto*

Jurusan Gizi Politeknik Kesehatan Kemenkes Tasikmalaya, Jawa Barat

*Korespondensi dengan author (kang_sumarto@yahoo.com)

Artikel ini dikirim pada tanggal 23 November 2015 dan dinyatakan diterima tanggal 10 Februari 2016. Artikel ini juga dipublikasi secara online melalui www.jatp.ift.or.id. Hak cipta dilindungi undang-undang. Dilarang diperbanyak untuk tujuan komersial.

Diproduksi oleh Indonesian Food Technologists® @2016

\begin{abstract}
Abstrak
Kebutuhan akan kedelai sebagai bahan baku tempe masih harus dipenuhi sebagian besarnya dari impor. Untuk itu, perlu dilakukan kajian untuk mencari bahan baku lain dari kacang non-kedelai asli dari produksi dalam negeri untuk menggantikan kedelai. Tujuan penelitian adalah mengetahui pengaruh penggunaan kacang nonkedelai terhadap sifat fisik, daya terima secara organoleptik, dan kandungan gizi produk tempe dari kacang nonkedelai. Jenis penelitian yang digunakan adalah eksperimen murni (true experiment) dengan menggunakan Rancangan Acak Kelompok. Kacang non-kedelai yang dianalisis adalah kacang bogor, kacang hijau,kacang merah, dan kacang tanah. Proses pembuatan tempe dari kacang non-kedelai (kacang bogor, kacang hijau, kacang merah, dan kacang tanah) pada prinsipnya sama dengan proses pembuatan tempe dari kacang kedelai. Prinsip dasar pembuatan tempe adalah pembersihan, pencucian, perebusan, perendaman, pencucian, penambahan inokulum, pengemasan dan fermentasi. Pengemasan yang baik adalah dengan menggunakan pengemas daun pisang. Sifat fisik (rendemen dan kadar air) tempe kacang non-kedelai hampir sama dengan tempe kacang kedelai. Sifat organoleptik kacang non-kedelai masih dapat diterima oleh panelis. Kandungan gizi (energi, karbohidrat, protein, dan lemak) tempe kacang non-kedelai berbeda dengan tempe kacang kedelai. Hasil ini menunjukkan bahwa kacang-kacangan tersebut berpotensi untuk dikembangkan menjadi alternatif bahan baku subtitusi kacang kedelai dalam pembuatan tempe.
\end{abstract}

Kata kunci: tempe, kacang-kacangan, sifat fisik, sifat organoleptik, kandungan gizi

\section{Abstract}

The need of soybean as raw materials of tempeh still have to be met largely by imports. To that end, the study needs to be done to look for other raw materials from others legumes non-soybean that native of domestic production to subtitute soybean. The research objective was to determine the effect of the use of non-soybeans on physical, organoleptic acceptability, and nutritional value of tempeh. This type of research was true experiment using a randomized block design. Others legumes non-soybean analyzed were Bambarra Groundnut (Kacang Bogor), mung beans, red kidney beans, and peanuts. The process of making tempeh from the non-soybeans (Kacang Bogor, mung beans, red kidney beans, and peanuts) are in principle the same as the process of making tempeh from soybean. The basic process of making tempeh is cleaning, washing, boiling, soaking, washing, addition of inoculum, packaging and fermentation. Good packaging is to use a banana leaf packaging. The physical properties (yield and moisture content) of non-soybeans tempeh are almost the same with soybean tempeh. Organoleptic properties of non-soybeans still can be accepted by the panelists. The content of nutrients (energy, carbohydrates, protein, and fat) non-soybeans tempeh different from soybean tempeh. These results indicate that the others legumes have the potential to be developed as an alternative raw material of substitution soybean tempeh.

Keywords: tempeh, legums, physical properties, organoleptic properties, nutritional value

\section{Pendahuluan}

Produksi kedelai pada tahun 2012 hanya sebesar 843,15 ribu ton, sementara kebutuhan secara nasional sebesar 2,3 juta ton ([BPS] 2014). Akhirnya, pemerintah melakukan impor kedelai dari negara lain untuk memenuhi kekurangan akan kebutuhan kedelai di dalam negeri. Padahal kedelai tersebut menjadi bahan baku utama untuk produk pangan yang dibuat di dalam negeri seperti tempe, tahu, tauco, kecap, susu kedelai, kembang tahu, dan lain sebagainya. Kedelai merupakan bahan pangan sumber protein nabati utama bagi masyarakat, khususnya di Indonesia (Muchtadi 2010).

Tempe merupakan produk olahan fermentasi yang berasal dari Indonesia dan selama ini berbahan baku kedelai. Penelitian tentang kandungan zat gizi dan non-gizi serta manfaat tempe kedelai telah banyak dilakukan. Proses fermentasi dalam pembuatan tempe dapat mempertahankan sebagian besar zat-zat gizi yang terkandung dalam kedelai, meningkatkan daya cerna proteinnya, serta meningkatkan kadar beberapa macam vitamin B (Muchtadi 2010). Kapang yang tumbuh pada tempe mampu menghasilkan beberapa 
enzim seperti enzim protease untuk mengurai protein menjadi peptida yang lebih pendek dan asam amino bebas, enzim lipase untuk mengurai lemak menjadi asam-asam lemak, dan enzim amilase untuk mengurai karbohidrat komplek menjadi senyawa yang lebih sederhana. Oleh karena itu tempe sangat baik untuk dikonsumsi oleh berbagai umur (dari bayi hingga lanjut usia).

Jika melihat potensi Indonesia yang mempunyai keanekaragam hayati yang sangat besar, seharusnya kita mampu memberikan solusi untuk mengatasi kelangkaan bahan baku kedelai untuk pembuatan tempe. Beberapa kacang-kacangan asli produksi dalam negeri sangat berpotensi untuk dikembangkan menjadi bahan baku tempe. Banyak jenis kacang-kacangan yang dapat digunakan dalam penelitian untuk pembuatan produk tempe, diantaranya kacang merah, kacang hijau, kacang bogor, dan kacang tanah.

Penelitian sebelumnya terkait dengan pengembangan produk tempe dari kacang non-kedelai telah dilakukan oleh (Wicaksono 2014), (Lestari 2014), (Sari 2014), dan (Iswandari 2006) yang mengembangkan tempe dari kacang merah dan kacang hijau. Wicaksono dan Lestari memberikan perlakuan persen aerasi di dalam kemasan plastik yang digunakan pada fermentasi tempe kacang merah (Wicaksono 2014) dan (Lestari 2014). Sari telah melakukan penelitian pengaruh jenis kapang terhadap mutu kimia dan aktivitas antimikroba fermentasi kacang merah (Sari 2014). Iswandari telah melakukan penelitian pembuatan tempe kacang hijau dan menganalisis kandungan isoflavon di dalamnya (Iswandari 2006).

Meskipun belum menunjukkan potensi pengembangan kacang non-kedelai sebagai bahan baku, (Haliza et al. 2007) juga telah menginventarisir penelitian tentang subtitusi kacang non-kedelai seperti kacang gude menjadi tempe. Untuk menyempurnakan hasil penelitian-penelitian di atas perlu dilakukan penelitian lebih lanjut. Penelitian selanjutnya diharapkan dapat menghasilkan standar prosedur pembuatan yang tepat dan pengembangan kacang non-kedelai lainnya menjadi tempe yang diterima oleh masyarakat. Selain itu, penelitian ini juga diharapkan dapat menentukan sifat fisik dan kandungan gizi tempe non-kedelai tersebut.

\section{Materi dan Metode}

Penelitian dilakukan laboratorium Teknologi Pangan, Jurusan Gizi dan laboratorium terpadu Poltekkes Kemenkes Tasikmalaya. Penelitian ini dilakukan pada bulan Desember 2014. Sampel kacang non-kedelai berasal dari pasar dan swalayan di Tasikmalaya.

Jenis penelitian yang digunakan adalah eksperimen murni (true experiment) dengan menggunakan Rancangan Acak Kelompok dengan 5 perlakuan dan 2 kali pengulangan. Perlakuan penelitian yang diterapkan dalam pembuatan tempe kacang nonkedelai adalah penggantian bahan baku kedelai dengan kacang lain (kacang merah, kacang hijau, kacang bogor, dan kacang tanah). Sebelumnya dilakukan penelitian pendahuluan untuk menetapkan komposisi bahan baku dan jenis kemasan yang lebih tepat untuk proses fermentasi dengan bahan baku kacangkacangan tersebut.

Proses pembuatan tempe kacang non-kedelai dilakukan dengan memodifikasi prosedur dari (Steinkraus et al. 1983), (Koswara 1995), dan (Iswandari 2006). Sifat fisik tempe yang dianalisis adalah pertumbuhan miselium (Lestari 2014), rendemen (Lestari 2014), dan kadar air ([AOAC] 2005). Sifat organoleptik tempe dianalisis menggunakan panelis terlatih (Setyaningsih et al. 2010). Kandungan gizi ditentukan dengan menghitung bahan baku yang digunakan berdasarkan data dari Tabel Komposisi Pangan Indonesia ([Persagi] 2009). Analisis data menggunakan program komputer MS Excel.

\section{Hasil dan Pembahasan}

Jenis Kacang

Kacang non-kedelai yang digunakan di dalam penelitian ini adalah kacang bogor, kacang hijau, kacang merah, dan kacang tanah. Kacang-kacang tersebut kemudian dibandingkan dengan kacang kedelai sebagai kontrol. Kacang-kacangan yang digunakan di dalam penelitian ini memiliki nama dalam bahasa daerah dan bahasa inggris yang berbeda-beda. Tabel 1 menunjukkan nama kacang yang digunakan dalam penelitian ini baik dalam nama latin, nama daerah, maupun dalam bahasa Inggris.

Tabel 1. Jenis Kacang yang Digunakan dalam Pembuatan Tempe

\begin{tabular}{|c|c|c|c|}
\hline $\begin{array}{l}\text { Nama } \\
\text { Kacang }\end{array}$ & Nama Latin & $\begin{array}{l}\text { Nama } \\
\text { Daerah/Lain }\end{array}$ & $\begin{array}{l}\text { Bahasa } \\
\text { Inggris }\end{array}$ \\
\hline $\begin{array}{l}\text { Kacang } \\
\text { Kedelai }\end{array}$ & Glycine max & $\begin{array}{l}\text { Kacang } \\
\text { Kedele }\end{array}$ & Soy Bean \\
\hline $\begin{array}{l}\text { Kacang } \\
\text { Bogor }\end{array}$ & Vigna subterranea & $\begin{array}{l}\text { Kacang } \\
\text { Banten }\end{array}$ & $\begin{array}{l}\text { Bambarra } \\
\text { Groundnut }\end{array}$ \\
\hline $\begin{array}{l}\text { Kacang } \\
\text { Hijau }\end{array}$ & Vigna radiata L. & $\begin{array}{l}\text { Kacang } \\
\text { ljo/Hejo }\end{array}$ & Mung Bean \\
\hline $\begin{array}{l}\text { Kacang } \\
\text { Merah }\end{array}$ & Vigna angularis & Kacang Garut & $\begin{array}{l}\text { Red Kidney } \\
\text { Bean }\end{array}$ \\
\hline $\begin{array}{l}\text { Kacang } \\
\text { Tanah }\end{array}$ & Arachis hypogae L. & Kacang Suuk & Peanuts \\
\hline
\end{tabular}

\section{Dimensi Kacang}

Kacang-kacangan yang digunakan di dalam penelitian ini memiliki dimensi atau ukuran yang berbeda. Perbedaan dimensi ini akan mempengaruhi tempe yang akan dihasilkannya. Untuk itu, pengenalan dimensi kacang-kacangan tersebut perlu diketahui.

Dimensi, khususnya diameter kacang-kacangan yang digunakan dalam penelitian telah diukur. Berdasarkan Tabel 2 terlihat bahwa dimensi atau diameter kacang kedelai tidak sama dengan kacang lainnya. Kacang kedelai memiliki diameter yang sama dengan kacang tanah. Kacang bogor dan kacang merah memiliki diameter yang lebih besar dibandingkan dengan kacang kedelai. Kacang hijau memiliki diameter yang lebih kecil dibandingkan kacang kedelai. Diameter tersebut akan mempengaruhi proses fermentasi dan penetrasi kapang pada pembuatan tempe, sehingga akan mempengaruhi kualitas tempe yang dihasilkannya. 
Tabel 2. Dimensi Kacang-Kacangan

\begin{tabular}{lc}
\hline Jenis & Dimensi/diameter $(\mathrm{cm})$ \\
\hline Kacang kedelai & 1 \\
Kacang bogor & 2 \\
Kacang hijau & 0,5 \\
Kacang merah & 1,5 \\
Kacang tanah & 1 \\
\hline
\end{tabular}

\section{Proses Pembuatan Tempe}

Standar proses pembuatan tempe kacang nonkedelai dilakukan dengan mencari, menganalisis, membandingkan, memilih, dan memodifikasi dari berbagai hasil penelitian yang telah dilakukan sebelumnya oleh peneliti lain. Pada dasarnya proses pembuatan tempe kacang non-kedelai dikembangkan berdasarkan proses pembuatan tempe kacang kedelai. Prinsip dasar pembuatan tempe adalah pembersihan, pencucian, perebusan, perendaman, pencucian, penambahan inokulum, pengemasan dan fermentasi (Utari 2011). Secara lengkap proses pembuatan tempe dapat dilihat pada Gambar 1.

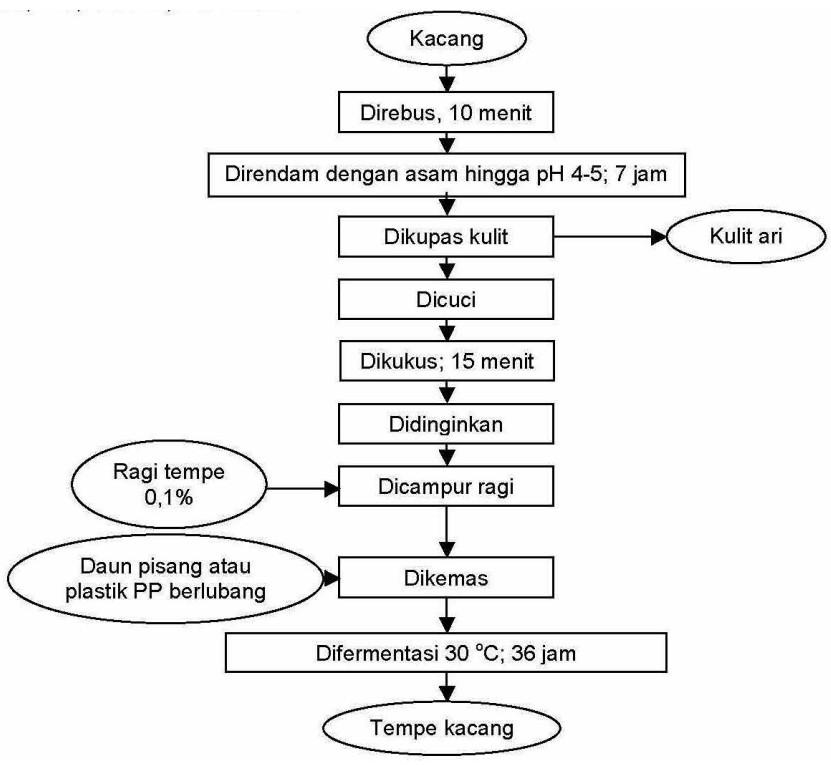

Gambar 1. Standar Proses Pembuatan Tempe Kacang NonKedelai

Perebusan. Tahap ini bertujuan agar kacang dapat menyerap air sebanyak mungkin, sehingga membuatnya lebih lunak dan memudahkan proses fermentasi (acidification) di tahap awal. Perebusan yang ideal dalam pembuatan tempe dilakukan sebanyak 2 kali dengan tujuan akhir memaksimalkan jumlah isoflavon tempe. Jika tanpa perebusan di tahap awal, maka dibutuhkan waktu perendaman yang lebih lama, dan akan muncul bau asam (Herman \& Karmini 1999). Proses perebusan yang kedua sebenarnya diperlukan untuk memastikan agar kacang dalam keadaan benar-benar matang dan untuk membunuh bakteri yang bersifat kontaminan.

Modifikasi pertama yang dilakukan dalam penelitian ini adalah penambahan proses pemanasan (perebusan atau pengukusan) di tahap awal. Penelitian (Suwarto 2011) menunjukkan bahwa pemanasan memberikan pengaruh yang siginifikan pada penurunan kandungan asam fitat tempe. Pemanasan juga dapat menurunkan sifat alergenisitas pada kacang-kacangan. Menurut (Wilson et al. 2005) sifat alergenisitas suatu bahan pangan dapat dipengaruhi oleh proses pemanasan, fermentasi, hidrolisis enzimatik, konjugasi dengan karbohidrat, rekayasa genetika dan proses ekstrusi. Proses pemanasan dari protein alergen kacang tanah pada suhu ekstrim dapat menurunkan kapasitas pengikatan lgE (Vissers et al. 2014). Pemanasan menyebabkan penurunan reaktivitas alergenisitas semakin tinggi (Sitorus 2014).

Pengupasan kulit kacang. Bertujuan agar asam laktat bisa masuk lebih mudah ke dalam biji kacang dan miselium tumbuh selama fermentasi (Herman \& Karmini 1999). Pengupasan kacang dalam skala kecil bisa dilakukan dengan menggunakan kaki, namun jika kacang (misalnya kacang kedelai) dalam jumlah besar menggunakan mesin mengupas.

Perendaman. Bertujuan agar terjadi fermentasi asam laktat dan terjadinya kondisi asam sehingga mendorong pertumbuhan mold tempe, yang akan tercapai jika $\mathrm{pH}$ sekitar $3,5-5,2$. Adanya campuran kulit kacang dalam tempe akan menghambat pertumbuhan bakteri asam laktat selama perendaman dan menurunkan acidification kacang (Herman \& Karmini 1999). Pertumbuhan bakteri ditandai dengan keluarnya bau asam saat perendaman serta adanya busa di permukaan air perendaman. Penambahkan cuka ke dalam air rendaman dapat mempercepat proses keasaman, bahkan bisa menghemat waktu perendaman hingga 10 jam. Keasaman dan perendaman juga menguntungkan pertumbuhan bakteri untuk sintesa vitamin B2, vitamin B6, vitamin B12, niacin, biotin, asam folat, dan asam pantotenat (Herman \& Karmini 1999). Pada penelitian ini dilakukan perendaman dengan asam cuka hingga $\mathrm{pH}$ 4-5 selama 7 jam.

Pencucian. Bertujuan agar kacang tidak menjadi asam dan menghilangkan lendir yang dihasilkan bakteri asam laktat. Adanya bakteri dan lendir akan menghalangi proses fermentasi tahap akhir. Setelah pencucian, beberapa produsen merebus kacang untuk kedua kalinya. Hal ini akan membuat biji kacang semakin lunak. Selain itu juga akan membunuh bakteri yang hidup dan berkembang biak selama perendaman (Herman \& Karmini 1999). Kacang dengan dua kali perebusan akan lebih bersih, lebih lama daya simpannya, dan rasa tidak asam (Utari 2011). Di dalam penelitian ini dilakukan pengukusan untuk mencegah rusaknya tekstur kacang.

Pendinginan. Bertujuan untuk mendinginkan sebelum kacang diberi ragi. Sambil menunggu kacang dingin, kacang juga dibersihkan dari kotoran yang mungkin masih ada. Kotoran yang biasanya terdapat dalam kacang adalah kerikil, ranting, dan kontaminan fisik lain.

Peragian. Kacang harus benar-benar bersih, kering dan dingin sebelum disebarkan ragi di permukaan kacang. Beberapa jenis ragi dicampur dengan tepung beras (digunakan dalam penelitian ini) atau tepung jagung, yang tujuannya untuk memudahkan ragi disebar dalam kacang. 
Pengemasan. Setelah peragian, maka kacang segera dikemas. Pengemasan bisa menggunakan daun pisang atau plastik (telah diberi lubang kecil untuk mendapatkan oksigen bagi pertumbuhan kapang). Menurut (Herman \& Karmini 1999), pertumbuhan kapang dari kacang yang dibungkus daun umumnya lebih cepat dibandingkan yang dibungkus plastik. Bagian pengemasan ini dijadikan sebagai perlakuan pada penelitian pendahuluan. Perlakuan penelitian dilakukan dengan membandingkan perbedaan penggunaan jenis kemasan yaitu daun pisang dan plastik polipropilen (PP) dengan aerasi yang berbeda.

Fermentasi. Setelah pengemasan selesai, kacang yang sudah dibungkus, diperam pada tempat yang dianggap lembab. Suhu tidak boleh terlalu dingin karena akan menghalangi pertumbuhan kapang. Suhu yang ideal berkisar $20{ }^{\circ} \mathrm{C}$ hingga $37{ }^{\circ} \mathrm{C}$ (di dalam penelitian ini dilakukan pada suhu $30{ }^{\circ} \mathrm{C}$ ). Jumlah ragi, suhu dan kelembaban adalah faktor penting untuk proses fermentasi (Herman \& Karmini 1999). Lama fermentasi yang dilakukan adalah sekitar 36 jam.
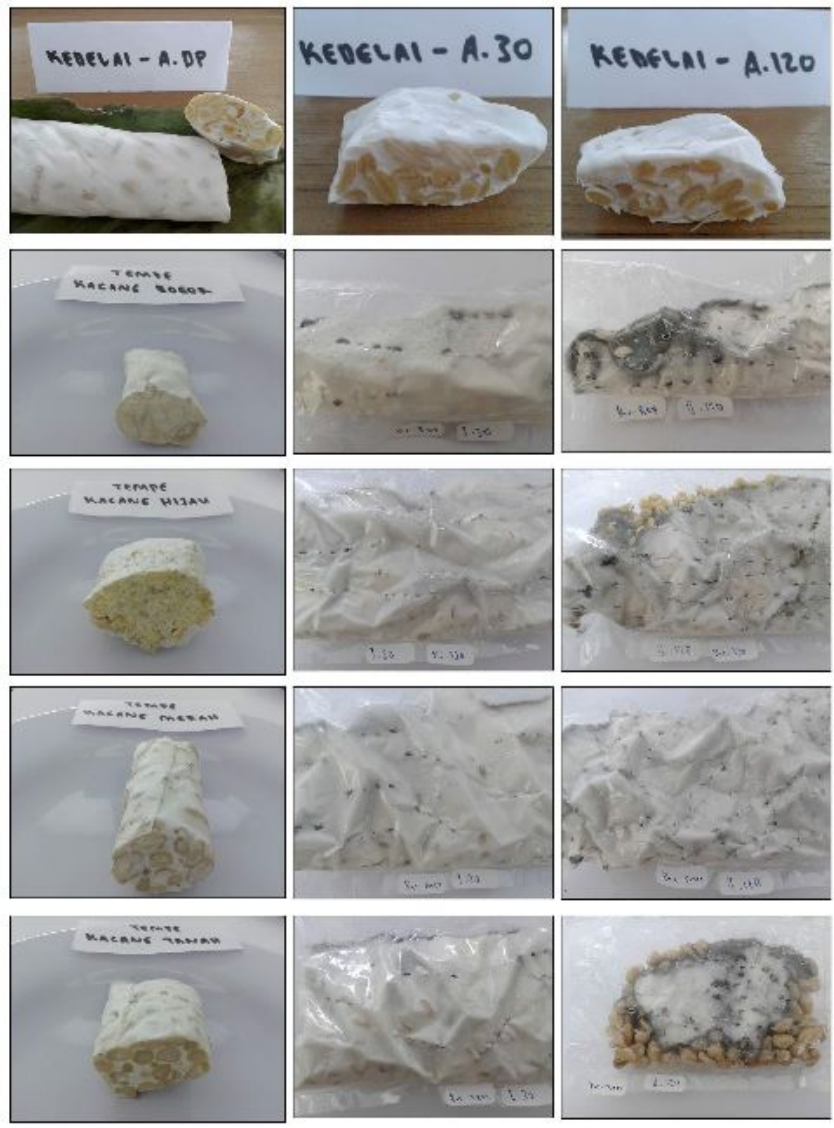

Gambar 2. Penampakan Pertumbuhan Miselium Tempe Kacang Keterangan: Kiri - Kanan = DP (Daun Pisang), A.30 (Plastik PP aerasi $1 \%$ ), A.120 (Plastik PP aerasi 5\%); Atas - bawah $=$ Kacang kedelai, Kacang bogor, Kacang hijau, Kacang merah, Kacang tanah

\section{Pertumbuhan Miselium}

Pertumbuhan miselium tempe kacang yang digunakan dalam penelitian ini dapat dilihat pada Gambar 2. Gambar 2 menunjukkan hasil pengamatan tempe kacang kedelai dan non-kedelai dari berbagai perlakuan pengemasan yang berbeda. Dari hasil tersebut terlihat bahwa hasil tempe terbaik adalah dengan pengemasan menggunakan daun pisang dari semua jenis kacang.

Pada tempe terutama dari kacang non-kedelai dengan menggunakan pengemas plastik polipropilen (PP) dengan aerasi $1 \%$ dan $5 \%$ memperlihatkan terdapatnya warna hitam. Daerah warna hitam lebih terlihat besar pada aerasi yang lebih besar (5\%). Hal ini menunjukkan bahwa kelebihan udara atau oksigen yang masuk ke dalam kacang akan mempengaruhi pertumbuhan kapang pada tempe tersebut.

Berdasarkan Gambar 2 terlihat bahwa pada seluruh sampel tempe kacang dengan kemasan daun pisang, permukaan tempe dapat tertutup oleh miselium kapang. Miselium berwarna putih dan tempe yang dihasilkan kompak. Namun pada tempe dengan kemasan plastik aerasi $1 \%$ dan $5 \%$ mempunyai tekstur yang kurang kompak. Pertumbuhan miselium dipengaruhi oleh jenis kapang yang digunakan, viabilitas laru, suhu, konsentrasi asam organik yang tidak terdisosiasi, serta pH (de Reu et al. 1993).

Kondisi inkubasi sangat mempengaruhi pertumbuhan kapang dan pembentukan miselium. Pembuatan lubang kemasan (aerasi) berperan dalam penyediaan oksigen untuk pertumbuhan kapang. Aerasi yang terlalu sedikit menyebabkan kapang kekurangan oksigen sehingga pertumbuhannya terhambat. Namun ketika lubang kemasan terlalu banyak, kapang akan tumbuh dengan cepat dan terjadi sporulasi (Kovac \& Raspor 1997). Hal ini tidak dikehendaki dalam pembuatan tempe. Sporulasi akan menyebabkan munculnya spora berwarna hitam pada permukaan tempe (Frazier 1967).

Tempe kacang merah dengan kemasan daun pisang memiliki penampakan yang baik. Hasil tersebut sesuai dengan penelitian (Lestari 2014) dan (Wicaksono 2014) yang menunjukkan bahwa tempe kacang merah yang dihasilkan pada penelitian tersebut mempunyai penampakan yang baik, miselium dapat menutup permukaan tempe, dan terbentuk tekstur kompak.

\section{Rendemen}

Rendemen tempe merupakan perbandingan bobot tempe (dalam gram) yang dihasilkan dengan total berat kacang sebelum fermentasi (dalam gram). Rendemen tempe sangat dipengaruhi oleh proses pembuatan tempe. Tabel 3 menunjukkan hasil pengukuran rendemen tempe kacang kedelai dan nonkedelai.

Tabel 3. Rendemen Tempe Kacang

\begin{tabular}{llcc}
\hline Jenis Tempe & \multicolumn{3}{c}{ Rendemen (\%) } \\
\cline { 2 - 4 } & A.DP* & A.30* & A.120* \\
\hline Kacang Kedelai & 98,00 & 95,00 & 89,00 \\
Kacang Bogor & 93,33 & 86,67 & 80,00 \\
Kacang Hijau & 95,00 & 91,25 & 81,25 \\
Kacang Merah & 94,29 & 92,86 & 85,71 \\
Kacang Tanah & 96,25 & 95,00 & 85,00 \\
\hline
\end{tabular}

Keterangan:

A.DP = kemasan daun pisang

A.30 = kemasan plastik PP dengan aerasi $1 \%$

A.120 = kemasan plastik PP dengan aerasi $5 \%$ 
Berdasarkan Tabel 3 terlihat bahwa setiap perlakuan kemasan dan bahan baku kacang yang digunakan memiliki rendemen yang berbeda. Secara berurutan untuk setiap jenis kacang memiliki rendemen yang semakin menurun dari kemasan daun pisang, plastik aerasi $1 \%$, dan plastik aerasi 5\%. Tempe dengan perlakuan kemasan daun pisang memiliki rendemen tertinggi dibandingkan dengan perlakuan lain untuk semua jenis tempe. Meskipun tempe kacang kedelai memiliki rendemen tertinggi dibandingkan dengan tempe kacang lainnya, tetapi secara umum perbedaan tersebut tidak terlalu besar. Semua jenis tempe memiliki rendemen $80,00 \%$ ke atas untuk semua jenis kemasan.

\section{Kadar Air}

Kadar air tempe hasil penelitian dari berbagai kacang memiliki nilai yang berbeda. Tempe yang diukur kadar airnya adalah tempe dengan perlakuan terbaik dari hasil pengamatan miselium dan rendemen yaitu dikemas dalam daun pisang. Pengukuran dilakukan sebanyak 2 kali (duplo) untuk masing-masing sampel. Secara lengkap hasil pengukuran kadar air tempe kacang kedelai dan non-kedelai dapat dilihat pada Tabel 4.

\begin{tabular}{lccccc} 
Tabel 4. Kadar Air Tempe Kacang & & \\
\hline Jenis Tempe & Ulangan & $\begin{array}{c}\text { Kadar air } \\
(\%)\end{array}$ & $\begin{array}{c}\text { Rata-rata } \pm \text { sd } \\
(\%)\end{array}$ \\
\hline Kacang Kedelai & I & 58,89 & 59,11 & $\pm 0,31$ \\
Kacang Bogor & II & 59,32 & & & \\
& I & 57,06 & 55,89 & $\pm 1,65$ \\
Kacang Hijau & II & 54,73 & & & \\
& I & 56,96 & 56,19 & $\pm 1,10$ \\
Kacang Merah & II & 55,41 & & & \\
& I & 61,83 & 61,79 & $\pm 0,06$ \\
Kacang Tanah & II & 61,75 & & & \\
& I & 33,23 & 32,00 & $\pm 1,74$ \\
& II & 30,77 & & & \\
\hline
\end{tabular}

Berdasarkan data pada Tabel 4 di atas terlihat bahwa semua jenis tempe memiliki kadar air di bawah $62 \%$. Nilai ini memenuhi Standar Nasional Indonesia (SNI) 3144:2009 tentang tempe, yakni maksimal 65\% ([BSN] 2009). Kadar air yang relatif tinggi tersebut menjadikan tempe sebagai salah satu jenis pangan yang cukup rawan ditumbuhi oleh mikroorganisme lain, seperti bakteri yang dapat menimbulkan kerusakan pangan.

\section{Sifat Organoleptik}

Uji sensori dilakukan dengan menggunakan uji rating hedonik untuk mengetahui tingkat kesukaan panelis tertentu terhadap tempe kacang kedelai dan non-kedelai. Sampel tempe yang diuji secara organoleptik adalah sampel terbaik dari perlakuan sebelumnya yaitu tempe yang dikemas dengan daun pisang. Tempe dipotong dengan ketebalan $1 \mathrm{~cm}$ dan digoreng dengan api sangat kecil selama 5 menit tanpa penambahan bumbu. Hasil uji organoleptik tempe kacang kedelai dan non-kedelai dapat dilihat pada Tabel 5.

Tabel 5. Hasil Uji Organoleptik Tempe Kacang

\begin{tabular}{lcccc}
\hline Jenis Tempe & \multicolumn{4}{c}{ Penilaian (1-5) } \\
\hline & Warna & Rasa & Aroma & Tekstur \\
\hline Kacang Kedelai & 4,3 & 3,8 & 4,0 & 3,8 \\
Kacang Bogor & 3,3 & 2,5 & 3,0 & 3,0 \\
Kacang Hijau & 2,8 & 3,3 & 3,0 & 2,8 \\
Kacang Merah & 3,3 & 2,3 & 2,5 & 2,8 \\
Kacang Tanah & 4,3 & 2,3 & 3,3 & 3,5 \\
\hline
\end{tabular}

Keterangan: skala 1 adalah sangat tidak suka dan skala 5 adalah sangat suka

Tabel 5 menunjukkan bahwa panelis memberikan penilaian yang beragam terhadap parameter warna, rasa, aroma, dan tekstur tempe kacang kedelai dan non-kedelai. Pada parameter warna panelis memberikan warna yang sama antara tempe kacang kedelai dan tempe kacang tanah, yaitu 4,3. Selain itu warna tempe kacang bogor dan tempe kacang merah pun dinilai cukup baik yaitu 3,3 (antara netral-3 dan suka-4). Hal ini menunjukkan bahwa warna tempe kacang non-kedelai khususnya tempe kacang bogor, tempe kacang merah, dan tempe kacang tanah dapat diterima oleh panelis.

Warna tempe sangat dipengaruhi oleh pertumbuhan miselium. Namun parameter warna yang dinilai dalam penelitian ini adalah warna tempe setelah digoreng. Penilaian terhadap parameter warna tempe kacang hijau cukup rendah yaitu 2,8 (antara tidak suka2 dan netral-3). Hal ini dapat disebabkan dari hasil penggorengan tempe kacang hijau yang memiliki ukuran diameter kacangnya lebih kecil dibandingkan dengan kacang lainnya. Ukuran ini mempengaruhi warna tempe kacang hijau yang sebelumnya diberikan perlakuan waktu dan suhu penggorengan yang sama dengan jenis tempe lain.

Panelis memberikan penilaian yang baik pada parameter rasa tempe kacang kedelai dan tempe kacang hijau. Pada parameter aroma panelis memberikan penilaian yang baik (cenderung suka) pada tempe kacang kedelai, tempe kacang bogor, tempe kacang hijau, dan tempe kacang tanah. Berdasarkan pada parameter tekstur, panelis memberikan penilaian yang baik (cenderung suka) untuk tempe kacang kedelai, tempe kacang bogor, dan tempe kacang tanah.

Berdasarkan penilaian pada hampir seluruh paramater, tempe kacang non-kedelai yang cenderung lebih disukai panelis adalah tempe dari kacang tanah. Kecuali pada parameter rasa, panelis memberikan penilaian yang cenderung suka pada parameter warna, aroma, dan tekstur. Panelis kurang suka rasa tempe kacang tanah karena adanya rasa pahit. Rasa ini dapat ditimbulkan dari bahan baku kacang tanah yang digunakan. Untuk itu, pemilihan bahan kacang tanah yang akan dijadikan sebagai bahan baku tempe perlu dilakukan dengan baik agar diperoleh kualitas tempe yang lebih disukai oleh panelis. 


\section{Kandungan Gizi}

Perhitungan kandungan gizi terdiri atas kalori, karbohidrat, protein, dan lemak. Perhitungan ini berdasarkan pada data dari Tabel Komposisi Pangan Indonesia ([Persagi] 2009) dan beberapa literatur lainnya. Perhitungan dilakukan pada sampel kacang kedelai dan kacang non-kedelai dengan hasil perlakuan terbaik yaitu dikemas dengan daun pisang. Asumsi perhitungan kandungan gizi tempe pada penelitian ini berdasarkan kandungan gizi bahan baku kacang yang digunakannya. Hal ini juga masih menjadi keterbatasan dalam penelitian ini. Hasil perhitungan estimasi kandungan gizi pada tempe kacang kedelai dan kacang non-kedelai dapat dilihat pada Tabel 6.

Tabel 6. Kandungan Gizi Tempe Kacang

\begin{tabular}{lcccc}
\hline $\begin{array}{l}\text { Nama } \\
\text { Tempe }\end{array}$ & \multicolumn{4}{c}{ Kandungan Zat Gizi per 100 gram } \\
\cline { 2 - 5 } & $\begin{array}{c}\text { Energi } \\
(\text { Kal) }\end{array}$ & $\begin{array}{c}\text { Karbohidrat } \\
(\mathrm{g})\end{array}$ & $\begin{array}{c}\text { Protein } \\
(\mathrm{g})\end{array}$ & $\begin{array}{c}\text { Lemak } \\
(\mathrm{g})\end{array}$ \\
\hline $\begin{array}{l}\text { Kacang } \\
\text { Kedelai }\end{array}$ & 400 & 32 & 35,1 & 17,7 \\
$\begin{array}{l}\text { Kacang } \\
\text { Bogor }\end{array}$ & 387 & 63,5 & 18,3 & 6,6 \\
$\begin{array}{l}\text { Kacang } \\
\text { Hijau } \\
\text { Kacang }\end{array}$ & 345 & 62,9 & 22,2 & 1,2 \\
$\begin{array}{l}\text { Merah } \\
\text { Kacang }\end{array}$ & 336 & 59,5 & 23,1 & 1,7 \\
Tanah & 606 & 16,1 & 28,5 & 47,5 \\
\hline
\end{tabular}

Berdasarkan Tabel 6 terlihat bahwa estimasi kandungan gizi pada tempe kacang kedelai dan tempe kacang non-kedelai memiliki nilai yang berbeda-beda. Perhitungan kandungan gizi per 100 gram produk tempe dengan nilai energi terbesar adalah kacang tanah. Hal ini dikarenakan kandungan lemak kacang tanah juga besar dalam menyumbangkan kandungan energi yang besar. Tempe kacang bogor, tempe kacang hijau, dan tempe kacang merah memiliki kandungan energi yang hampir sama.

Kandungan karbohidrat tempe kacang nonkedelai memiliki angka yang berbeda dengan tempe kedelai. Kandungan karbohidrat terkecil terdapat pada tempe kacang tanah. Kandungan karbohidrat tempe kacang bogor, kacang hijau, dan kacang merah lebih besar dibandingkan dengan tempe kedelai. Nilai karbohidrat tersebut belum dihitung berdasarkan uji di laboratorium. Penelitian (Wicaksono 2014) menunjukkan bahwa kadar karbohidrat tempe kacang merah sebesar $22.38 \%$. Hal ini berbeda dengan data pada Tabel 6 yang masih berdasarkan estimasi perhitungan kandungan gizi.

Kandungan protein tempe kacang kedelai dan tempe kacang non-kedelai memiliki angka yang berbeda. Berdasarkan estimasi perhitungan kandungan protein pada Tabel 6 menunjukkan bahwa tempe kacang bogor, tempe kacang hijau, tempe kacang merah, dan tempe kacang merah memiliki kandungan protein yang lebih kecil dibandingkan tempe kacang kedelai. Nilai kandungan protein tersebut juga berbeda dengan hasil uji di laboratorium oleh Wicaksono khususnya terhadap tempe kacang merah yang menunjukkan bahwa kadar protein kasar yaitu $12.92 \%$ (bb) (Wicaksono 2014). Nilai ini lebih rendah dibandingkan dengan standar SNI 3144:2009 ([BSN] 2009) yang menetapkan kadar protein tempe kedelai minimal $16.00 \%$ (bb). Aktivitas proteolitik $R$. oligosporus dan $R$. oryzae sangat berperan dalam peningkatan protein selama proses fermentasi tempe. Kapang menggunakan asam-asam amino (albumin, globulin) dan basa terlarut untuk pertumbuhannya (Handoyo \& Morita 2006). Analisis pangan tempe kedelai menunjukkan bahwa kandungan asam amino tertinggi pada tempe adalah arginin dan asam lemak tertinggi adalah asam linoleat (Utari 2011).

Kandungan lemak pada tempe kacang kedelai dan tempe kacang non-kedelai menunjukkan angka yang berbeda. Berdasarkan estimasi perhitungan kandungan lemak, tempe kacang tanah memiliki kandungan lemak yang paling tinggi. Kandungan lemak pada tempe kacang bogor, kacang hijau, dan kacang merah lebih rendah dibandingkan dengan tempe kacang kedelai. Nilai tersebut juga berbeda dengan hasil pengujian di laboratorium yang dilakukan oleh (Wicaksono 2014) yang menunjukkan kadar lemak tempe kacang merah adalah $0.11 \%$. Nilai ini lebih rendah dibandingkan dengan SNI 3144:2009 ([BSN] 2009 ) yakni minimal $10 \%$. $R$. oligosporus dan $R$. oryzae menghasilkan enzim lipase yang akan mengubah lemak menjadi trigliserida dan asam lemak bebas selama fermentasi (Asp et al. 1983). Kapang menggunakan asam lemak bebas tersebut sebagai sumber karbon (de Reu et al. 1993).

\section{Kesimpulan}

Proses pembuatan tempe dari kacang nonkedelai (kacang bogor, kacang hijau, kacang merah, dan kacang tanah) pada prinsipnya sama dengan proses pembuatan tempe dari kacang kedelai. Prinsip dasar pembuatan tempe adalah pembersihan, pencucian, perebusan, perendaman, pencucian, penambahan inokulum, pengemasan dan fermentasi. Pengemasan yang baik adalah dengan menggunakan pengemas daun pisang. Sifat fisik (rendemen dan kadar air) tempe kacang non-kedelai hampir sama dengan tempe kacang kedelai. Sifat organoleptik kacang nonkedelai masih dapat diterima oleh panelis. Kandungan gizi (energi, karbohidrat, protein, dan lemak) tempe kacang non-kedelai berbeda dengan tempe kacang kedelai.

\section{Daftar Pustaka}

AOAC, A. of O.A.C., 2005. Official Methods of Analysis.

BPS, B.P.S., 2014. Produksi Tanaman Pangan 2014, Jakarta.

BSN, B.S.N., 2009. SNI 3144:2009 - Tempe Kedelai, Indonesia.

Persagi, P.A.G.I., 2009. Tabel Komposisi Pangan Indonesia, Jakarta: Elex Media Komputindo.

Asp, N.G. et al., 1983. Rapid enzymatic assay of insoluble and soluble dietary fiber. Journal of Agricultural and Food Chemistry, 31, pp.476-482.

Frazier, W.., 1967. Food Microbiology, USA: Mc Graw Hill Company. 
Haliza, W., Purwani, E.Y. \& Thahir, R., 2007. Bahan Baku Tempe dan Tahu. Buletin Teknologi Pascapanen Pertanian, 3, pp.1-8.

Handoyo, T. \& Morita, N., 2006. Structural and functional properties of fermented soybean (Tempeh) by using Rhizopus oligosporus. International Journal of Food Properties, 9(2), pp.347-355.

Available at: http://www.tandfonline.com/doi/abs/10.1080/1094 2910500224746.

Herman \& Karmini, M., 1999. The Development of Tempe Technology. In J. Agranoff, ed. The Complete Handbook of Tempe. Singapura: The American Soybean Association, pp. 80-92.

Iswandari, R., 2006. Studi kandungan isoflavon pada kacang hijau (Vigna radiata L.), tempe kacang hijau, dan bubur kacang hijau. Institut Pertanian Bogor.

Koswara, S., 1995. Teknologi Pengolahan Kedelai, Jakarta: Pustaka Sinar Harapan.

Kovac, B. \& Raspor, P., 1997. The Use of the Mould Rhizopus Olifosporus in Food Production. Food Technology and Biotechnology, 35, pp.69-73.

Lestari, I.A., 2014. Pengaruh ketebalan dan persen aerasi terhadap karakteristik tempe grits kacang merah (Phaseolus vulgaris L.) ukuran 8 mesh. Institut Pertanian Bogor.

Muchtadi, D., 2010. Kedelai Komponen untuk Kesehatan, Bandung: Alfabeta.

De Reu, J.C. et al., 1993. Temperature control in solid substrate fermentation through discontinous rotation. Applied Microbiology and Biotechnology, 40, pp.261-265.
Sari, D.R., 2014. Pengaruh jenis kapang terhadap mutu kimia dan aktivitas antimikroba tempe kacang merah (Phaseolus vulgaris L.). Institut Pertanian Bogor.

Setyaningsih, D., Apriyantono, A. \& Sari, M.P., 2010. Analisis Sensori untuk Industri Pangan dan Agro, Bogor: IPB Press.

Sitorus, S.R., 2014. Perubahan alergenisitas protein kacang kedelai (Glycine max) dan kacang bogor (Vigna subterranea) akibat pengolahan dengan panas. Institut Pertanian Bogor.

Steinkraus, K. et al. eds., 1983. Handbook of Indigenous Fermented Foods, New York: Marcel Dekker.

Suwarto, A.T.C., 2011. Kinetika perubahan asam fitat pada tempe selama proses pemanasan. Institut Pertanian Bogor.

Utari, D.M., 2011. Efek intervensi tempe terhadap profil lipid, superoksida dismutase, $L D L$ teroksidasi dan malondialdehyde pada wanita menopause. Institut Pertanian Bogor.

Vissers, Y. et al., 2014. Effect of heating and glycation on the allergenicity of $2 S$ albumins (Ara $h$ 2/6) from peanut. PLoS One, 6(8), p.e23998.

Wicaksono, A.T., 2014. Pengaruh ketebalan dan persen aerasi kemasan terhadap sifat fisikokimia tempe grits kacang merah (Phaseolus vulgaris L.). Institut Pertanian Bogor.

Wilson, S., Blaschek, K. \& de Meja, E., 2005. Allergenic protein in soybean: processing and reduction of P34 allergenicity. Nutr Rev, 63(2), pp.47-58. 